\title{
ABILITY TO DEAL WITH IT: SELF-MANAGEMENT AND PROBLEM-SOLVING SKILLS, MOTIVATION AND ROUTINES HELPED HIGH-SCHOOL STUDENTS DURING THE COVID-19 PANDEMIC
}

\author{
Liena Hačatrjana \\ University of Latvia, Latvia
}

\begin{abstract}
As the COVID-19 pandemic unfolded, more than 1.5 billion students worldwide started learning remotely, and they faced a range of challenges: a lack of immediate support from teachers, problems with technology, psychological well-being and difficulties in independently coping with their duties. The aim of this study was to understand what helped students cope with distance learning and what hindered and made it difficult for students, as well to examine students' self-assessed problem-solving and self-management skills. Qualitative and quantitative methods were used in the study with 358 students aged $M=16.65$ years. Participants answered two open-ended questions and filled the ProblemSolving Questionnaire and the Metacognitive Awareness Scale. Content analysis of students' answers shows that most frequently students' goal-orientation, determination to succeed, diligence and specific routines helped them deal with the distance learning. On the contrary, lack of motivation (among other psychological difficulties), distractions, lack of routines, and felt pressure to manage all school tasks were most frequently the aspects that hindered students from coping with the distance learning. Results show significant correlation between most scales of self-assessed problem solving and self-management skills. Students with higher result in total score of self-reported problem-solving skills felt less stress about the distance learning and the pandemic in general.
\end{abstract}

Keywords: adolescence, COVID-19, distance learning, high-school, problem-solving skills, selfmanagement skills.

\section{Introduction}

The COVID-19 pandemic and the distance learning during the pandemic have brought many challenges both at the level of organizations (schools) and at the level of individual students. Students had to adapt to a relatively more individual and self-managed learning process, with less immediate support and guidance from teachers during the process, which 
inevitably required the application and development of various skills, such as planning and organizing their time and responsibilities, and coping with difficulties using problem solving. Studies published to date highlight various difficulties faced by students during a pandemic, such as mental and physical health, difficulties with friends, family and socialization, difficulties with learning and routines (Scott et al., 2020; Rogers, Ha \& Ockey, 2021). One of the main issues and risks that stem from this situation is that distance learning can further increase inequalities in the quality of knowledge acquired between students of different backgrounds or level of skills, including increasing the risk of dropping out of school, and contributing to a decline in learning performance (Azevedo et al., 2020; Kaffenberger, 2021). Therefore, it is important to assess what skills and routines are necessary for students to effectively cope with distance learning.

The distance learning during COVID-19 pandemic has been an unprecedented situation in the modern times (with such wide options of using technology in education), thus making this a unique experience for students. In order to cope with distance learning (and non-standard situations in general) students had to apply and further develop a range of skills, including self-management, planning skills and problem-solving skills. It is unclear to what extent they possessed the necessary skills at the beginning of the pandemic. While it is important to do quantitative assessment monitoring students' skills and achievement during this time, it is equally important to assess and document the students' experience based on their own unique viewpoint. Therefore, the aim of this study was to understand what helped students cope with distance learning and what hindered and made it difficult for students (based on their own views), as well to examine students' self-assessed problem-solving and self-management skills based on a questionnaire assessment.

Self-regulation skills (and self-management skills in general) are involved in self-regulated learning. Self-regulation consists of three major components of metacognition: 1) forethought - planning; 2) performance monitoring; 3) self-reflection - evaluation (Zimmerman, 2008). Students use metacognitive skills in learning to proactively think, perform and self-reflect (Carter et al., 2020). It is crucial for students to have self-management skills to effectively learn remotely, and the circumstances during the pandemic demanded that students applied their self-management skills to the extent that they possessed them.

In the current study, problem solving is defined as a set of complex, goal-directed cognitive, affective, and behavioral operations for adapting to internal and external demands, to achieve desired goals (see Heppner \& Krauskopf, 1987; Nezu, 2004); Problem solving is operationalized here as consisting of three components: 1) Problem Solving Ability-Confidence is 
a belief in one's problem-solving abilities and having positive experience in solving problems; 2) Problem-solving actions (originally called "ApproachAvoidance Style" by Heppner, 1982) is one's tendency of performing such actions and strategies that represent successful problem solving; 3) Personal Control is the belief in one's emotional and behavioral control while solving problems (Heppner, 1982). To conclude, having specific skills and strategies to solve problems and having the confidence about one's ability is important to successfully deal with different types of problems.

Pre-pandemic research has shown a link between academic performance and problem-solving skills assessed with several types of measurements (Greiff, Kretzschmar, Müller, Spinath \& Martin, 2014; Greiff, Wüstenberg, Molnár, Fischer, Funke, \& Csapó, 2013). Self-regulation is also related to course performance and academic performance (Pintrich et al., 1993; Zimmerman \& Martinez-Pons, 1988; Abd-El-Fattah, 2010; Veenman et al., 2014). It is currently crucial to find out what kind of skills are particularly important to maintain academic achievement and motivation during such a new situation with distance learning to further develop tools for strengthening these skills.

\section{Method}

Data from a total of 358 students studying in grades 9-12 with an average age of $M=16.65$ years were analyzed, $218(60.9 \%)$ of the respondents, were girls and 140 (39.1\%) were boys; 69 respondents study in the 9th grade, 106 respondents study in the 10th grade, 100 respondents study in the $11^{\text {th }}$ grade, and 83 respondents study in the $12^{\text {th }}$ grade (during school year 2020/2021).

Participants answered questions about their experiences and feelings during distance learning (for example, felt stress about COVID-19 pandemic and about distance learning), they completed the Problem-Solving Questionnaire (Heppner, 1982) with 32 items in three scales. During the previous research with Latvian adapted version, the scales of the questionnaire showed good internal consistency: Problem solving ability-confidence scale ( $\alpha=0.77$ ), Problem solving actions ( $\alpha=0.66)$, and Personalcontrol scale ( $\alpha=0.68$ ) (Sudraba \& Strīke, 2020). Students completed the Metacognitive Awareness scale with 9 items for assessing self-management skills of planning, monitoring and evaluating that showed high internal consistency for the total score $(\alpha=0.92)$ (Vanags \& Pestovs, 2019).

Participants were asked two open-ended questions regarding of 1) what had helped them cope during distance learning and 2) what had hindered them to deal with distance learning? They also answered demographic questions. 
The data were collected in cooperation with schools during online classes where students of each class gathered at one specific time. The data were collected using an online platform in February 2021, and participation was voluntary and anonymous.

\section{Results}

First, the main results based on the qualitative analysis are presented, followed by the results derived from the obtained quantitative data. The goal of the researcher was to gather and compile unique experience from students' own viewpoint described in their own words. Therefore, summative content analysis was performed to analyze the answers to open-ended questions of students by systematically identifying and classifying themes that appear in the text (Shannon \& Hsieh, 2005). The researcher read all the answers of students and based on the content developed categories (themes) that appear in the answers. The categories were also counted based on the frequency in the students' answers.

The categories were further analyzed based on their type: whether the category represents an individual level aspect (for example, internal motivation to succeed or psychological difficulties) or external level (wider) aspects (e. g., difficulty to study because of the background noise and sharing a room with other family members). The aim was to form conclusions regarding the type of the category and possibility to act on it. For example, it is not possible to individually change regulations or restrictions during the pandemic, but it is possible to train certain skills of students to organize their time and learning better. The further purpose of this analysis was to develop conclusions and hypotheses regarding how the disruptive factors could be reduced and how the contributory factors could be stimulated to help students to adapt to distance learning and other unprecedented situations that may come in the future.

Table 1 summarizes students' responses about what has helped them cope with distance learning during the COVID-19 pandemic. The answers are grouped into categories and counted to see how often each category appeared in the students' answers.

As we can see in Table 1 , such individual aspects as determination to succeed (students mentioned motivation and willingness to keep their "status" and grades) and diligence (students mentioned ability to force themselves to do tasks on time), as well as planning skills and routines (e. g., writing down all the tasks, planning in what order to do tasks etc.) were mentioned most frequently as helpful in dealing with the distance learning. 
Table 1. Analysis of aspects that helped students during the distance learning

\begin{tabular}{|l|l|l|}
\hline Category & Type of the category & Frequency \\
\hline $\begin{array}{l}\text { Goal-orientation and motivation to } \\
\text { succeed (includes responsibility and } \\
\text { insistence) }\end{array}$ & $\begin{array}{l}\text { Individual level: personality } \\
\text { and motivation }\end{array}$ & 148 \\
\hline $\begin{array}{l}\text { Self-discipline and sense of duty } \\
\text { (includes diligence and forcing oneself } \\
\text { to do tasks) }\end{array}$ & $\begin{array}{l}\text { Individual level: personality } \\
\text { and attitude }\end{array}$ & 121 \\
\hline $\begin{array}{l}\text { Planning and organization skills } \\
\text { (includes specific routines and actions } \\
\text { that are described in the students' } \\
\text { answers) }\end{array}$ & Individual level: skills & 68 \\
\hline $\begin{array}{l}\text { Optimism (includes the ability to keep } \\
\text { calm and not stress about everything) }\end{array}$ & Individual level: personality & 29 \\
\hline $\begin{array}{l}\text { Hobbies and physical activities (e. g., } \\
\text { music, sports) }\end{array}$ & $\begin{array}{l}\text { External or individual level } \\
\text { (depending on whether the } \\
\text { activities were organized or } \\
\text { individually initiated) }\end{array}$ & 22 \\
\hline $\begin{array}{l}\text { Individualism and independence } \\
\text { (e. g., likes being alone and studying } \\
\text { independently) }\end{array}$ & Individual level: personality & 20 \\
\hline Good technology skills & Individual level: skills & 18 \\
\hline $\begin{array}{l}\text { Fast thinking and flexibility (includes } \\
\text { creativity and ability to get everything } \\
\text { done "last minute") }\end{array}$ & Individual level: abilities & 17 \\
\hline $\begin{array}{l}\text { Communication (includes asking for } \\
\text { advice when necessary) }\end{array}$ & Individual level: personality & 14 \\
\hline $\begin{array}{l}\text { Passive attitude/avoidance (includes } \\
\text { accepting low grades, indifference) }\end{array}$ & $\begin{array}{l}\text { Individual level: personality } \\
\text { and motivation }\end{array}$ & 7 \\
\hline
\end{tabular}

Similarly, the disruptive factors were analyzed from students' answers. As can be seen in the Table 2, when we look at the individual level aspects, most frequently students' responses show a lack of motivation and other psychological difficulties, as well as difficulties in learning and understanding the subject alone that indicates a lack of self-management skills, self-regulated learning skills and problem-solving skills. If we look at external level aspects, we see that factors related to lack of school-like regime and routines, lack of appropriate learning environment, including distractions at home (sharing a room and background noise, etc.) are most often mentioned as interfering factors. It can be concluded that before the pandemic the routines and physical school environment (for example, getting ready in the morning, walking to school, and sitting in one's place in the physical classroom) had helped students to focus on their studies. 
Table 2. Analysis of aspects that hindered students dealing with the distance learning

\begin{tabular}{|c|c|c|}
\hline Category & Type of the category & Frequency \\
\hline $\begin{array}{l}\text { Lack of motivation and depression } \\
\text { (includes "laziness" anxiety and } \\
\text { problems with concentration) }\end{array}$ & $\begin{array}{l}\text { Individual level: psychological } \\
\text { well-being }\end{array}$ & 158 \\
\hline $\begin{array}{l}\text { Environment and lack of regime } \\
\text { (includes distractions at home and lack } \\
\text { of daily routines) }\end{array}$ & $\begin{array}{l}\text { External level: family and } \\
\text { physical environment }\end{array}$ & 91 \\
\hline $\begin{array}{l}\text { Sense of a large amount of schoolwork } \\
\text { (includes felt pressure to do it all) }\end{array}$ & $\begin{array}{l}\text { External level: school and } \\
\text { organizational level }\end{array}$ & 77 \\
\hline $\begin{array}{l}\text { Difficulty to learn individually } \\
\text { (includes difficulty to plan time } \\
\text { and grasp new knowledge without } \\
\text { immediate support) }\end{array}$ & $\begin{array}{l}\text { Individual level: skills (self- } \\
\text { directed learning and problem- } \\
\text { solving skills) }\end{array}$ & 51 \\
\hline $\begin{array}{l}\text { Teachers' inconsistency (includes } \\
\text { planning inconsistencies at school } \\
\text { level) }\end{array}$ & $\begin{array}{l}\text { External level: school and } \\
\text { organizational level }\end{array}$ & 42 \\
\hline $\begin{array}{l}\text { Sense of lack of support (includes lack } \\
\text { of immediate feedback, advice, control } \\
\text { and guidance) }\end{array}$ & $\begin{array}{l}\text { Individual and external level: } \\
\text { self-regulated learning skills } \\
\text { and teachers' actions }\end{array}$ & 31 \\
\hline $\begin{array}{l}\text { Lack of socialization (includes lack of } \\
\text { formal and informal communication) }\end{array}$ & $\begin{array}{l}\text { External level: can be altered } \\
\text { via organized online activities } \\
\text { Individual level: personality } \\
\text { and communication }\end{array}$ & 29 \\
\hline $\begin{array}{l}\text { Decrease of physical well-being } \\
\text { (includes problems from the long } \\
\text { screen time, sitting and general lack of } \\
\text { physical activities) }\end{array}$ & $\begin{array}{l}\text { Individual level: skills, } \\
\text { practices and routines }\end{array}$ & 27 \\
\hline $\begin{array}{l}\text { Problems with technologies (includes } \\
\text { internet or computer problems or lack } \\
\text { of them) }\end{array}$ & External level: equipment & 21 \\
\hline $\begin{array}{l}\text { Stress related to COVID-19 (includes } \\
\text { stress about finances, health, global } \\
\text { situation and restrictions) }\end{array}$ & External level & 11 \\
\hline
\end{tabular}

Further an analysis of quantitative data that were gathered during the study is reported, starting with psychometrics of two questionnaires. The Metacognitive awareness scale shows good total internal consistency ( $\alpha=0.86$ ) in the current sample, compared to $\alpha=0.92$ in the original study (Vanags \& Pestovs, 2019); with also good internal consistency for the subscales: Planning ( $\alpha=0.83$ ), Monitoring $(\alpha=0.70)$ and Evaluation ( $\alpha=0.76$ ). The Problem-solving inventory also shows good internal consistency for total scale $(\alpha=0.86)$, and for the subscales: Problem solving ability-confidence ( $\alpha=0.84)$, Solving-actions ( $\alpha=0.75$ ), 
and Personal-control ( $\alpha=0.72$ ). In previous Latvian research the internal consistency of the three scales was accordingly: $\alpha=0.77, \alpha=0.66$, and $\alpha=0.68$, but the mean age of participants was higher $(M=23.9$, $S D=5.7$ ) (Sudraba \& Strīke, 2020).

Table 3 shows that most subscales of both surveys show statistically significant mutual correlations. Correlation analysis also shows that the lower the student's self-assessed problem-solving skills, the more the student has indicated they had felt stress about the COVID-19 pandemic in general $(r=-0.15, \mathrm{p}=0.004)$, as well as the stress about distance learning $(r=-0.22, \mathrm{p}=0.000)$. Such correlations were not found with self-management skills.

Table 3. Correlations between problem-solving and metacognitive awareness

\begin{tabular}{|l|c|l|c|c|}
\hline & $\begin{array}{l}\text { Problem } \\
\text { solving ability } \\
\text { confidence }\end{array}$ & $\begin{array}{l}\text { Problem } \\
\text { solving } \\
\text { actions }\end{array}$ & $\begin{array}{l}\text { Personal } \\
\text { control }\end{array}$ & $\begin{array}{l}\text { Total } \\
\text { Problem- } \\
\text { solving scale }\end{array}$ \\
\hline Planning & $0.36^{* *}$ & $0.44^{* *}$ & $0.23^{* *}$ & $0.44^{* *}$ \\
\hline Monitoring & $0.18^{* *}$ & $0.42^{* *}$ & $0.13^{*}$ & $0.31^{* *}$ \\
\hline Evaluation & $0.18^{* *}$ & $0.44^{* *}$ & 0.08 & $0.30^{* *}$ \\
\hline $\begin{array}{l}\text { Total Meta- } \\
\text { cognition scale }\end{array}$ & $0.30^{* *}$ & $0.53^{* *}$ & $0.17^{* *}$ & $0.43^{* *}$ \\
\hline
\end{tabular}

$* p<0.05 ; * * p<0.01$

\section{Discussion}

During this study factors that have helped and hindered students during the COVID-19 related distance learning were assessed, that leads to understanding how students can be helped in case of similar unexpected situations in the future and how their skills can be developed to deal with new situations in general. The questions were formed to gather students' unique viewpoints about what had helped and what had disturbed them during the distance learning process. As it was presented in the results section, a wide range of helpful and disruptive aspects appeared in the students' answers. Internal or individual level aspects were mentioned most frequently (such as ones concerning psychological well-being, feeling motivated or not motivated, and having or not having certain learning and organizational skills). On the contrary, external level factors, for example stress about the COVID-19 pandemic and restrictions, as well as hardship with technologies were mentioned less often.

As can be seen in the qualitative analysis, special attention should be paid to the psychological health of students and the signs of depression, 
anxiety and difficulty concentrating. Psychological well-being is important for students to maintain their motivation to study and deal with learning online. The amount of published research on students during COVID-19 is limited at the time of preparing this article; their methodologies, samples and focus varies. The results of the current study are generally in line with previous research on well-being of youth published during COVID-19 pandemic (Scott et al., 2020).

Students' self-management skills are still in their development process at high-school, and external guidance, control and support from teachers is crucial at this stage. Therefore, during the distance learning it is important to find alternatives to "the teacher being right beside in the classroom". Previous research has shown that even more mature samples compared to the current sample (undergraduate level students) report lack of time management skills, guidance and self-management during online classes (Fidalgo, Thormann, Kulyk, et al. 2020).

The results indicate that planning, organizational skills, specific routines and regime help students cope with distance learning. Activities that imitate the school and classroom environment could be implemented during the distance learning, for example, it could be a virtual "bell as the class starts" a virtual "arrival at school in the morning" (for example, checking-in in the morning via online) or another similar activity. But such activities have to be planned at the class or school level. Students, on the other hand, can individually focus on activities that imitate "getting ready for school in the morning" or "walking to school" for example, by taking a quick walk in the morning. Data in general show that more physical activities and being outdoors could also help students. Parents together with students must think about how to prevent distractions in the home environment and set up a place for learning, and support implementation of the helpful routines.

Socialization is also an important domain during adolescence, and it was impacted during the pandemic, showing also in the results of the current research. In their answers students have indicated that they lack socializing both regarding informal topics ("hanging out with friends") and formal topics ("talk about whether we fully understand what the teacher just taught us"), thus indicating that socializing is an important part of acquiring knowledge and the learning process. Research with undergraduate students suggest similar patterns regarding difficulties with communication and discussions during the distance learning (Amir et al., 2020). Lack of feeling socialized can be reduced to some extent by schoolwork done in pairs or in small groups (online or otherwise, based on the restrictions during the pandemic).

Considering that most subscales of both self-assessment type surveys (problem-solving and self-management) show statistically significant 
mutual correlations, it can be concluded that students who are more confident and experienced in successfully solving their problems also report higher self-management skills during learning (performing actions of planning, monitoring and evaluation). Results also indicate that the lower the student's self-assessed problem-solving skills, the more the student has indicated they had felt stress about the COVID-19 pandemic in general, as well as the stress about distance learning. It means that students with higher self-reported problem-solving skills indicated they felt less stress about distance learning.

\section{Limitations and future research}

When analyzing these results, one must keep in mind the research focus and methods used in the particular study. This study focused specifically on the distance learning, not coping with the pandemic in general. It can be assumed that the results and students' answers could differ if the question asked to students focused on dealing with the pandemic in general. Also, the analysis is limited to the current sample of 358 students from Latvia with mean age of 16 years, therefore it cannot be generalized to broader age groups or to the whole population. Self-assessment surveys were used in the study, and conclusions must be interpreted accordingly. Participation in the study was organized during online classes of students, but it cannot be ruled out that students with a lower level of motivation did not attend the class and did not fill out the whole survey. It must be noted that the current research was implemented during the so called "second wave" of the pandemic in February 2021, and the students' answers represent their unique point of view at this time.

One of the purposes of doing a qualitative analysis is to form conclusions and propose ideas and hypothesis for further research to validate these conclusions. Based on the content analysis of students' answers the author proposes that: 1) Students' ability to deal with the distance learning can be increased by reducing the discovered negative aspects and by cultivating the positive aspects, as much as possible. 2) There are aspects that are a priori more vulnerable to change both in the list of positive aspects (for example, we can teach students a set of particular organizing and planning skills and strategies, but it is harder to change personality factors) and in the list of the negative aspects (for example, we can teach students to prepare their physical space for learning without disruptions, but it would be harder to change the school system and the amount that students have to learn during a certain period of time). 3) The main focus in the field of psychology regarding further scientific research or educational development programs should be on the aspects that can be worked on and 
changed systematically and at the individual level of students (for example, including development of planning skills in the lessons). These hypotheses and conclusions should be tested in further studies and by creating and programs or materials for development of students' skills.

\section{Conclusions}

During this research, the aspects that helped and hindered students cope with distance learning were assessed. Based on the results presented in the article, it can be concluded that students have had difficulties in coping with the distance learning during the COVID-19 pandemic. Both helping and disturbing aspects are related to external (school and organizational) factors and individual factors, such as students' own motivation and skills. Analysis of students' answers about what has helped them during the distance learning shows that most frequently students' goal-orientation, determination to succeed, diligence and specific routines or skills have helped them to deal with the distance learning. On the contrary, lack of motivation (among other psychological difficulties), distractions and lack of routines, as well as the feeling of pressure to deal with all the schoolwork, were most frequently mentioned aspects that hindered students from coping with the distance learning. Students who assessed themselves higher on the scale of problem-solving skills indicated less felt stress about the pandemic and specifically about the distance learning process.

\section{Acknowledgements}

The research is supported by European Regional Development Fund under the activity "Post-doctoral Research Aid" project "Relationship between students' self-management and problem-solving skills and changes in academic achievement during face to face and distance learning situations" No. 1.1.1.2/VIAA/4/20/697.

\section{References}

Abd-El-Fattah, S. (2010). Garrison's Model of Self-Directed Learning: Preliminary Validation and Relationship to Academic Achievement. The Spanish Journal of Psychology, 13 (2), 586-596. https://doi:10.1017/S1138741600002262

Amir, L. R., Tanti, I., Maharani, D. A., Wimardhani, Y. S., Julia, V., Sulijaya, B., \& Puspitawati, R. (2020). Student perspective of classroom and distance learning during COVID-19 pandemic in the undergraduate dental study program Universitas Indonesia. BMC Medical Education, 20 (392). https://doi.org/10.1186/s12909-020-02312-0

Azevedo, J. P., Hasan, A., Goldemberg, D., Iqbal, S. A., \& Geven, K. (2020). Simulating the Potential Impacts of COVID-19 School Closures on Schooling and Learning Outcomes: A Set of Global Estimates. Policy Research Working Paper, No. 9284. World Bank, Washington, DC. 
Carter Jr, R. A., Rice, M., Yang, S., \& Jackson, H. A. (2020). Self-regulated learning in online learning environments: strategies for remote learning. Information and Learning Sciences, 121 (5/6), 321-329. https://doi.org/10.1108/ILS-04-2020-0114

Greiff, S., Kretzschmar, A., Müller, J. C., Spinath, B., \& Martin, R. (2014). The ComputerBased Assessment of Complex Problem Solving and How It Is Influenced by Students' Information and Communication Technology Literacy. Journal of Educational Psychology, 106 (3), 666-680. https://doi: 10.1037/a0035426

Greiff, S., Wüstenberg, S., Molnár, G., Fischer, A., Funke, J., \& Csapó, B. (2013). Complex problem solving in educational contexts-Something beyond g: Concept, assessment, measurement invariance, and construct validity. Journal of Educational Psychology, 105 (2), 364-379.

Fidalgo, P., Thormann, J., Kulyk, O. et al. (2020). Students' perceptions on distance education: A multinational study. International Journal of Educational Technologies in Higher Education, 17. https://doi.org/10.1186/s41239-020-00194-2

Heppner, P. P., \& Krauskopf, C. J. (1987). An information-processing approach to personal problem solving. The Counseling Psychologist, 15 (3), 371-447. https://doi. org/10.1177/0011000087153001

Heppner, P. P., \& Petersen, C. H. (1982). The development and implications of a personal problem solving inventory. Journal of Counseling Psychology, 29(1), 66-75. https://doi: 10.1037/0022-0167.29.1.66

Kaffenberger, M. (2021). Modelling the long-run learning impact of the COVID-19 learning shock: Actions to (more than) mitigate loss. International Journal of Educational Development, 81, https://doi.org/10.1016/j.ijedudev.2020.102326

Nezu, A. M. (2004). Problem solving and behavior therapy revisited. Behavior Therapy, 35 (1), 1-33. https://doi.org/10.1016/S0005-7894(04)80002-9

Pintrich, P. R., Smith, D. A. F., Garcia, T., Mckeachie, W. J. (1993). Reliability and Predictive Validity of the Motivated Strategies for Learning Questionnaire (MSLQ). Educational and Psychological Measurement, 53 (3), 801-813. https://doi:10.1177/ 0013164493053003024

Rogers, A. A., Ha, T., \& Ockey, S. (2021). Adolescents' Perceived Socio-Emotional Impact of COVID-19 and Implications for Mental Health: Results From a U.S.-Based Mixed-Methods Study. Journal of Adolescent Health, 68, 43-52

Scott, S. R., Rivera, K. A., Rushing, E., Manczak, E. M., Rozek, C. S., \& Doom, J. R. (2020). "I Hate This": A Qualitative Analysis of Adolescents' Self-Reported Challenges During the COVID-19 Pandemic. Journal of Adolescent Health, p. 1-8, https://doi. org $/ 10.1016 / \mathrm{j}$.jadohealth.2020.11.010

Shannon, S. E., \& Hsieh, H.-F. (2005). Three Approaches to Qualitative Content Analysis. Qualitative Health Research, 15 (9), 1277-1288. https://doi.org/10.1177/ 1049732305276687

Sudraba, V., \& Strīke, I. (2020). D tipa personības iezīmju un problēmu risināšanas spēju saistība studentiem. (Correlation between Type D Personality Traits and Problem Solving in Students). Proceedings of the International Scientific Conference SOCIETY. INTEGRATION. EDUCATION, Volume VI, 391-400. http://dx.doi.org/10.17770/ sie2020vol6.5026

Vanags, E., \& Pestovs, P. (2019). Development of Metacognition Awareness Scale for 10th-12th Grade. Proceedings of ATEE Spring conference. Innovations, Technologies and Research in Education, 231-240, University of Latvia Press. 
Veenman, M. V. J., Hesselink, R. D., Sleeuwaegen, S., \& Liem, S. I. E. (2014). Assessing Developmental Differences in Metacognitive Skills With Computer Logfiles: Gender by Age Interactions. Psychological Topics 23(1), 99-113.

Zimmerman, B. J., \& Martinez-Pons, M. (1988). Construct validation of a strategy model of student self-regulated learning. Journal of Educational Psychology, 80, 284-290.

Zimmerman, B. J. (2008). Investigating self-regulation and motivation: historical background, methodological developments, and future prospects. American Educational Research Journal, 45 (1), 166-183. 